\title{
PECULIARITIES OF SOYBEAN SYMBIOTIC APPARATUS FORMATION AND CROP PRODUCTIVITY UNDER THE INFLUENCE OF RHIZOHUMIN, TRACE NUTRIENTS AND PLANT GROWTH STIMULATOR
}

\author{
Murach O. M. ${ }^{1}$, Volkogon V. V. ${ }^{2}$ \\ ${ }^{1}$ Institute of Agriculture of North-East NAAS \\ 1, Zelena str., Sad, Sumy region, 42343 \\ ${ }^{2}$ Institute of Agricultural Microbiology and Agroidustrial Production NAAS, \\ 97, Shevchenko str., Chernihiv, 14027 Ukraine \\ rifam@ukrpost.ua
}

Interaction peculiarities of various technological factors such as presowing inoculation of soybean seeds with microbial preparations Rhizohumin, trace nutrients, plant growth stimulator Biosyl in different combinations followed by the efficiency study of foliar application of trace nutrients and Biosyl solutions on preinoculated plants was investigated in the stationary field experiment. Use of Rhizohumin followed by the foliar application of trace nutrients was shown to be the most promising solution. The highest crop productivity was observed at inoculation of soybean seeds with Rhizohumin and foliar crops spraying with trace nutrients and growth stimulator.

Key words: soybean, bakterization, Rhizohumin, trace nutrients, plant growth stimulator, Biosyl.

The prospects of effective use of microbial preparations based on active rhizobia strains, trace nutrients and plant growth stimulators, applied individually in legume crop growing technologies was proven by numerous studies. However, even at their applications in agricultural technologies implementation the genetic potential of crop yield is not implemented in full. The question is - can these technological factors be combined in single process? There is no clear answer, primarily because of the small number of the performed studies. There are reports indicating enhancement of the symbiotic nitrogen fixation process by combined use of pre-sowing seed bakterization and growth regulators [1, 2]. At the same time, there are certain precautions at combined use of microbial preparations with growth regulators, because both preparations contain physiologically active substances, which at overdose may have negative effect on the crop productivity process [3].

Thus, the purpose of our research was to study the effectiveness of a combination of pre sowing seed bakterization, trace nutrients and plant growth stimulator in the soybeans crop growing technology.

Materials and methods. The study was conducted during the $2012-2013$ years in stationary field experiment in the Institute of Agriculture of North-East NAAS on typical black low humus mildy alkaline middle sandy loam soils, with the following characteristics of arable layer: humus content $-4.1 \%, \mathrm{pH}_{\text {salt }}-6.3$, the amount of absorbed bases - $31 \mathrm{mg}$ eq., mobile forms of phosphorus - 11.3, exchangeable potassium -9.2 , easy hydrolysable nitrogen by Kornfield -11.2 $\mathrm{mg} / 100 \mathrm{~g}$. 
The study was conducted on soybean varieties KyVin, entered to the Register of Plant Varieties in Ukraine in 2008.

Total plot area in the experiment $-80 \mathrm{~m}^{2}$, accounting area $-60 \mathrm{~m}^{2}, 4$ time repetition, systematic plot placement. Pre-crop - winter wheat.

Soil preparation, sowing, crops maintenance and harvesting was performed in accordance to regional recommendations.

Seeding at 700 thousand seeds per hectare rate, in narrow rows $(15 \mathrm{~cm})$.

Soybean seeds were pretreated with Maxim XL 035 FS (1 liters/ton) disinfectant at 14 days prior to the planting. At planting the preparations conditioned by the scheme of experiment were used as recommended by the manufacturer [4].

For pre-sowing seed inoculation the biological preparation of complex action Rhizohumin (TU 24.1-00497360-003:2007) with Bradyrhizobium japonicum M-8 agent was used. Given preparation contains physiologically active substance of natural origin (auxins, cytokinins, amino acids, humic acids), trace nutrients in chelated form in starting concentrations. This biological preparation have multifunctional effects on plant growth and development, increases field seed germination and seed vigor, promotes root system development and active plantbacterial nitrogen fixing symbiosis, intensifies the process of photosynthesis in plants. That ensures increased assimilation surface area of roots and above ground mass in inoculated plants that affects nutrient absorption. In addition, as a result of activity of introduced bacteria, plants get extra nitrogen and phosphorus [4].

Besides pre sowing bakterization the seeds in some variants were pre-treated with solution of chelated trace nutrients from "Reacom" and plant growth stimulator Biosyl (manufacturer - Science and Technology Center "Agrobiotech" National Academy of Sciences of Ukraine and Ministry of Education and Science of Ukraine). In some variants the use of trace nutrients and plant growth stimulator for seed treatment was combined with Rhizohumin. In some variants trace nutrients and Biosyl were also investigated as foliar during the growing season, including bacterized plants. The scheme of the experiment is given in the following tables.

Biometric studies were carried out using conventional methods [5]. The effectiveness of legume rhizobial symbiosis was estimated in the budding, flowering and pods formation phase using nodules quantity, weight and nitrogenase activity. Symbiotic nitrogen fixation activity was determined using acetylene reduction method on the gas chromatograph Chrom-4 [6]. Soybean yield was accounted using conventional methods [5]. Statistical analysis of the results was performed in accordance to the existing methods [5] and using the Statistica 6.0 software package.

Soybeans seeds were tested for protein content (total nitrogen, followed by conversion) and fats [7].

Results and discussion. Determination of the number of nitrogen fixing nodules on the roots of soybean plants of the dynamics had demonstrated relatively high indices in the control, which indicates the presence of native populations of soybean rhizobia in the soil. Nevertheless, pre-sowing seed inoculation with microbial preparation had ensured a significant increase in the number of nodules on the roots (Table 1), which was evident during both years of research. Application of trace nutrients and Biosyl as seeds treatment had also contributed to the some extent 
in nodules number increase promoting symbiosis with the aboriginal rhizobia. During some growing stages, these figures were significantly higher than the control. Combination of Rhizohumin with the trace nutrients with growth stimulator as well as their joint application for seed treatment had not enhanced nodulation activity. The increase of nodulation activity was observed only in variants with combined use of microbial preparation with trace nutrients (pod formation stage, 2013).

The foliar application of trace nutrients and Biosyl had slightly promoted the nodulation activity, but its efficiency was lower than the corresponding values obtained when using given preparations for pre-sowing seeds treatment with Rhizohumin. Separated in time application of studied preparations (seed treatment with Rhizohumin, and foliar application of trace nutrients and growth stimulator) had resulted in the highest number of nodules through the experiment. In certain stages high nodulation activity (compared to the variant with Rhizohumin) was detected in variants where seeds inoculation with Rhizohumin was combined either with foliar application of trace nutrients or growth stimulator, while this effect was not stable.

Table 1. Dynamics of nodules development on soybean roots under the influence of studied preparations and varied means of their use.

\begin{tabular}{|c|c|c|c|c|c|c|}
\hline \multirow{3}{*}{ Variants } & \multicolumn{6}{|c|}{ Number of nodules, pcs./plant } \\
\hline & \multicolumn{3}{|c|}{2012} & \multicolumn{3}{|c|}{2013} \\
\hline & I & II & III & I & II & III \\
\hline Without treatment & 10,5 & 14,3 & 16,4 & 31,7 & 31,7 & 38,2 \\
\hline \multicolumn{7}{|c|}{ Seed treatment } \\
\hline Rhizohumin & 17,2 & 23,6 & 26,3 & 43,0 & 52,9 & 53,3 \\
\hline Trace nutrients & 11,9 & 15,9 & 17,7 & 38,8 & 42,6 & 52,4 \\
\hline Growth regulator & 14,4 & 20,1 & 23,7 & 38,4 & 41,1 & 51,0 \\
\hline $\begin{array}{l}\text { Trace nutrients }+ \\
\text { growth regulator }\end{array}$ & 14,0 & 19,7 & 17,6 & 39,6 & 43,0 & 51,0 \\
\hline $\begin{array}{l}\text { Rhizohumin }+ \\
\text { trace nutrients }\end{array}$ & 16,9 & 23,2 & 27,2 & 45,8 & 49,0 & 71,6 \\
\hline $\begin{array}{l}\text { Rhizohumin }+ \\
\text { growth regulator }\end{array}$ & 15,2 & 18,9 & 22,8 & 33,0 & 36,2 & 49,0 \\
\hline $\begin{array}{l}\text { Rhizohumin }+ \text { trace } \\
\text { nutrients }+ \text { growth regulator }\end{array}$ & 12,2 & 15,3 & 19,5 & 33,2 & 37,3 & 47,9 \\
\hline \multicolumn{7}{|c|}{ Foliar application } \\
\hline Trace nutrients & 11,5 & 16,1 & 18,9 & 34,6 & 33,8 & 40,9 \\
\hline Growth regulator & 11,7 & 15,9 & 18,0 & 31,6 & 42,3 & 43,2 \\
\hline $\begin{array}{l}\text { Trace nutrients }+ \\
\text { growth regulator }\end{array}$ & 11,1 & 16,6 & 22,8 & 32,9 & 38,9 & 46,9 \\
\hline $\begin{array}{l}\text { Rhizohumin* + trace } \\
\text { nutrients }\end{array}$ & 14,4 & 20,0 & 24,0 & 48,3 & 45,9 & 65,0 \\
\hline $\begin{array}{l}\text { Rhizohumin* }+ \\
\text { growth regulator }\end{array}$ & 13,6 & 19,4 & 22,9 & 39,7 & 60,0 & 54,6 \\
\hline $\begin{array}{l}\text { Rhizohumin* + trace } \\
\text { nutrients }+ \text { growth regulator }\end{array}$ & 19,6 & 25,2 & 30,4 & 55,7 & 63,8 & 71,9 \\
\hline $\mathrm{LSD}_{05}$ & 2,2 & 1,5 & 3,5 & 5,7 & 15,2 & 19,0 \\
\hline
\end{tabular}

Note: “*” hereinafter indicates pre-sowing seeds bacterization;

I - budding stage; II - flowering stage; III - pod formation stage. 
Similar peculiarities, but with some differences, were also noted for the dried nodules weight indices (Table 2). In particular, high indices were observed in variants with Rhizohumin use combined with foliar application of trace nutrients. Except for one stage (flowering stage, 2013) the increase of nodules weight compared to the single microbial preparation use were noticed. The combination of "Rhizohumin and foliar growth regulator" had not affected the nodules weight. The distinctive effect was observed in the variant with Rhizohumin application followed with the foliar spraying of crops with trace nutrients and Biosyl.

Thus, the formation and development of nodules on the roots of soybean was more active in variants with seeds inoculation with microbial preparation Rhizohumin and was enhanced by foliar application with the solutions of chelated trace nutrients and plant growth stimulator.

Table 2. Accumulation of nodules weight on the roots of soybean under the influence of Rhizohumin, trace nutrients and plant growth stimulator

\begin{tabular}{|c|c|c|c|c|c|c|}
\hline \multirow{3}{*}{ Variants } & \multicolumn{6}{|c|}{ Weight of nodules, $\mathrm{g} /$ plant } \\
\hline & \multicolumn{3}{|c|}{2012} & \multicolumn{3}{|c|}{2013} \\
\hline & I & II & III & I & II & III \\
\hline Without treatment & 0,06 & 0,29 & 0,40 & 0,06 & 0,09 & 0,23 \\
\hline \multicolumn{7}{|c|}{ Обробка насіння } \\
\hline Rhizohumin & 0,13 & 0,77 & 0,98 & 0,11 & 0,19 & 0,34 \\
\hline Trace nutrients & 0,10 & 0,57 & 0,69 & 0,10 & 0,16 & 0,33 \\
\hline Growth regulator & 0,12 & 0,66 & 0,78 & 0,09 & 0,15 & 0,30 \\
\hline $\begin{array}{l}\text { Trace nutrients }+ \\
\text { growth regulator }\end{array}$ & 0,11 & 0,60 & 0,72 & 0,11 & 0,17 & 0,34 \\
\hline $\begin{array}{l}\text { Rhizohumin }+ \\
\text { trace nutrients }\end{array}$ & 0,13 & 0,78 & 0,94 & 0,15 & 0,23 & 0,43 \\
\hline $\begin{array}{l}\text { Rhizohumin }+ \\
\text { growth regulator }\end{array}$ & 0,11 & 0,49 & 0,60 & 0,06 & 0,12 & 0,27 \\
\hline $\begin{array}{l}\text { Rhizohumin + trace } \\
\text { nutrients }+ \\
\text { growth regulator }\end{array}$ & 0,10 & 0,62 & 0,75 & 0,08 & 0,15 & 0,26 \\
\hline \multicolumn{7}{|c|}{ Foliar application } \\
\hline Trace nutrients & 0,08 & 0,34 & 0,43 & 0,09 & 0,14 & 0,27 \\
\hline Growth regulator & 0,09 & 0,36 & 0,50 & 0,07 & 0,12 & 0,27 \\
\hline $\begin{array}{l}\text { Trace nutrients }+ \\
\text { growth regulator }\end{array}$ & 0,09 & 0,39 & 0,46 & 0,10 & 0,14 & 0,26 \\
\hline $\begin{array}{l}\text { Rhizohumin* + trace } \\
\text { nutrients }\end{array}$ & 0,16 & 0,96 & 1,20 & 0,14 & 0,20 & 0,50 \\
\hline $\begin{array}{l}\text { Rhizohumin* } \\
\text { growth regulator }\end{array}$ & 0,11 & 0,73 & 0,89 & 0,10 & 0,19 & 0,36 \\
\hline $\begin{array}{l}\text { Rhizohumin* + trace } \\
\text { nutrients }+ \text { growth regulator }\end{array}$ & 0,18 & 1,08 & 1,33 & 0,12 & 0,24 & 0,45 \\
\hline LSD05 & 0,04 & 0,11 & 0,15 & 0,05 & 0,09 & 0,15 \\
\hline
\end{tabular}


Determination of changes of nitrogen fixation activity in nodules had shown a significant enhancement of nitrogen fixation process in variants with pre-sowing seeds inoculation with Rhizohumin (Table 3). In 2012 microbial preparation had boosted NF activity $2-4$ times as compared to the control. In 2013 studies the lower levels of nitrogen fixation activity were observed, mainly due to unfavorable weather conditions. However, the peculiarities marked previously regarding the bacterization influence on the process had remained. It should be noted that during some organogenesis stage of soybean plants pre-sowing seeds treatment with Rhizohumin combined with foliar application of trace nutrients or Biosyl had caused the increase of nitrogen fixing activity as compared to the variant with Rhizohumin bacterization only. Nevertheless, these activity bursts were occasional rather than stable.

High activity indices as compared to the variant with single Rhizohumin use were observed in the variants with foliar treatment of pre-inoculated plants with the solution of trace nutrients in 2012. Activity indices close to the observed were also indicated in the variants with crops treatment with trace nutrients and Biosyl. In 2013 the showed effect was observed only during the late growth stages.

\section{Table 3. Effect of Rhizohumin, trace nutrients and Biosyl on the activity of symbiotic nitrogen fixation dynamics}

\begin{tabular}{|c|c|c|c|c|c|c|}
\hline \multirow{3}{*}{ Variants } & \multicolumn{6}{|c|}{ Nitrogen fixation, $\mu \mathrm{mol} \mathrm{C}_{2} \mathrm{H}_{4} /$ plant / hour } \\
\hline & \multicolumn{3}{|c|}{2012} & \multicolumn{3}{|c|}{2013} \\
\hline & I & II & III & I & II & III \\
\hline Without treatment & 2,6 & 5,7 & 4,9 & 0,1 & 0,3 & 1,2 \\
\hline \multicolumn{7}{|c|}{ Обробка насіння } \\
\hline Rhizohumin & 10,3 & 19,3 & 11,2 & 0,6 & 1,7 & 2,4 \\
\hline Trace nutrients & 6,7 & 11,2 & 6,7 & 0,4 & 0,4 & 1,7 \\
\hline Growth regulator & 7,9 & 14,8 & 14,1 & 0,3 & 0,5 & 2,7 \\
\hline $\begin{array}{l}\text { Trace nutrients + } \\
\text { growth regulator }\end{array}$ & 5,8 & 12,2 & 6,7 & 0,3 & 0,7 & 2,0 \\
\hline $\begin{array}{l}\text { Rhizohumin + } \\
\text { trace nutrients }\end{array}$ & 13,5 & 19,2 & 15,6 & 0,3 & 0,5 & 3,9 \\
\hline $\begin{array}{l}\text { Rhizohumin }+ \\
\text { growth regulator }\end{array}$ & 7,6 & 9,7 & 6,0 & 0,1 & 0,4 & 1,5 \\
\hline $\begin{array}{l}\text { Rhizohumin }+ \text { trace nutrients }+ \\
\text { growth regulator }\end{array}$ & 5,8 & 12,2 & 10,0 & 0,2 & 0,3 & 1,6 \\
\hline \multicolumn{7}{|c|}{ Foliar application } \\
\hline Trace nutrients & 7,1 & 9,7 & 6,3 & 0,2 & 0,5 & 1,7 \\
\hline Growth regulator & 3,8 & 12,1 & 5,8 & 0,3 & 0,6 & 1,6 \\
\hline $\begin{array}{l}\text { Trace nutrients }+ \\
\text { growth regulator }\end{array}$ & 6,5 & 8,1 & 6,3 & 0,3 & 0,5 & 1,9 \\
\hline Rhizohumin* + trace nutrients & 21,1 & 23,5 & 14,1 & 0,3 & 1,1 & 2,4 \\
\hline $\begin{array}{l}\text { Rhizohumin*+ } \\
\text { growth regulator }\end{array}$ & 8,0 & 15,4 & 10,3 & 0,4 & 1,1 & 2,4 \\
\hline $\begin{array}{l}\text { Rhizohumin* } * \text { trace nutrients }+ \\
\text { growth regulator }\end{array}$ & 16,4 & 23,1 & 15,3 & 0,4 & 1,3 & 2,4 \\
\hline LSD05 & 1,9 & 2,5 & 2,2 & 0,2 & 0,7 & 0,8 \\
\hline
\end{tabular}


Study of soybean productivity in 2012 had showed the upward trend for all investigated factors. Nevertheless, use of Rhizohumin was showed to be the most efficient (tab. 4).

Use of microbial preparation for pre-sowing seeds inoculation with subsequent foliar spraying of crops with trace nutrients was statistically significant as compared to the absolute control. Statistically significant influence was also observed in the variant with application of all three preparations separated in time (Rhizohumin - for seed treatment, trace nutrients and Biosyl - foliar application). In 2013 the use of Rhizohumin had ensured reliable increase of crop productivity. Productivity indices were also high in variants with foliar treatment of bacterized plants with trace nutrients and growth regulator used separately and in combination. Averaging yield indices had indicated the promising use of pre-sowing seeds treatment with Rhizohumin, as well as separate application of microbial preparation and trace nutrients and combination of trace nutrients and growth regulator used as foliars on bacterized plants.

\section{Table 4. Influence of biological preparation, trace nutrients and Biosyl on soybean} crop productivity

\begin{tabular}{|c|c|c|c|}
\hline \multirow{2}{*}{ Variants } & \multicolumn{3}{|c|}{ Yield, $\mathrm{t} / \mathrm{ha}$} \\
\hline & 2012 & 2013 & Average \\
\hline Without treatment & 2,13 & 2,36 & 2,25 \\
\hline \multicolumn{4}{|c|}{ Обробка насіння } \\
\hline Rhizohumin & 2,69 & 2,72 & 2,71 \\
\hline Trace nutrients & 2,42 & 2,57 & 2,50 \\
\hline Growth regulator & 2,53 & 2,63 & 2,58 \\
\hline $\begin{array}{l}\text { Trace nutrients }+ \\
\text { growth regulator }\end{array}$ & 2,47 & 2,68 & 2,58 \\
\hline $\begin{array}{l}\text { Rhizohumin }+ \\
\text { trace nutrients }\end{array}$ & 2,71 & 2,75 & 2,73 \\
\hline $\begin{array}{l}\text { Rhizohumin }+ \\
\text { growth regulator }\end{array}$ & 2,34 & 2,45 & 2,40 \\
\hline $\begin{array}{l}\text { Rhizohumin }+ \text { trace nutrients }+ \\
\text { growth regulator }\end{array}$ & 2,50 & 2,53 & 2,52 \\
\hline \multicolumn{4}{|c|}{ Foliar application } \\
\hline Trace nutrients & 2,21 & 2,54 & 2,38 \\
\hline Growth regulator & 2,28 & 2,48 & 2,38 \\
\hline $\begin{array}{l}\text { Trace nutrients }+ \\
\text { growth regulator }\end{array}$ & 2,25 & 2,59 & 2,42 \\
\hline Rhizohumin $*+$ trace nutrients & 2,82 & 2,84 & 2,83 \\
\hline $\begin{array}{l}\text { Rhizohumin* }{ }^{*}+ \\
\text { growth regulator }\end{array}$ & 2,63 & 2,80 & 2,72 \\
\hline $\begin{array}{l}\text { Rhizohumin* }+ \text { trace nutrients }+ \\
\text { growth regulator }\end{array}$ & 2,99 & 2,93 & 2,96 \\
\hline LSD05 & 0,42 & 0,25 & \\
\hline
\end{tabular}


It should be noted that the differences between the mentioned variants were not statistically significant, but their comparing with the absolute control values indicates the reliability of crop productivity increase.

It was shown that use of Rhizohumin for pre-sowing seeds bacterizatin had ensured increase of seeds quality as it was shown in study of protein and fat levels during 2012 (Table 5). Use of microbial preparation for seed treatment with trace nutrients and growth regulator as foliars in soybean growing technology had also improved grain quality as compared to the control. However, it was not statistically proven when comparing to the variant with seeds bacterization.

No significant changes in the studied parameters were observed in 2013, except for the variant with Rhizohumin and foliar application of trace nutrients where the growth of fat content was observed. However, it should be noted a clear trend to positive changes in variants with Rhizohumin use alone and in combination of all three studied factors separated in time.

Table 5. Influence of technological means on the grain quality of soybeans

\begin{tabular}{|c|c|c|c|c|}
\hline \multirow{2}{*}{ Variants } & \multicolumn{2}{|c|}{2012} & \multicolumn{2}{|c|}{2013} \\
\hline & $\mathrm{I}^{* *}$ & $\mathrm{II} * * *$ & $\mathrm{I}$ & II \\
\hline Without treatment & 29,5 & 19,6 & 32,1 & 23,2 \\
\hline \multicolumn{5}{|c|}{ Обробка насіння } \\
\hline Rhizohumin & 34,2 & 24,0 & 33,5 & 24,4 \\
\hline Trace nutrients & 33,7 & 21,8 & 33,0 & 23,5 \\
\hline Growth regulator & 32,1 & 23,9 & 33,1 & 24,0 \\
\hline $\begin{array}{l}\text { Trace nutrients }+ \\
\text { growth regulator }\end{array}$ & 32,7 & 23,5 & 33,5 & 24,3 \\
\hline $\begin{array}{l}\text { Rhizohumin }+ \\
\text { trace nutrients }\end{array}$ & 33,4 & 23,6 & 33,8 & 24,8 \\
\hline $\begin{array}{l}\text { Rhizohumin }+ \\
\text { growth regulator }\end{array}$ & 32,2 & 21,5 & 32,4 & 23,8 \\
\hline $\begin{array}{l}\text { Rhizohumin }+ \text { trace nutrients } \\
+ \\
\text { growth regulator }\end{array}$ & 30,7 & 21,3 & 32,5 & 24,2 \\
\hline \multicolumn{5}{|c|}{ Foliar application } \\
\hline Trace nutrients & 30,4 & 21,9 & 33,4 & 24,2 \\
\hline Growth regulator & 31,3 & 21,5 & 32,8 & 23,7 \\
\hline $\begin{array}{l}\text { Trace nutrients }+ \\
\text { growth regulator }\end{array}$ & 31,9 & 21,4 & 33,3 & 24,0 \\
\hline $\begin{array}{l}\text { Rhizohumin* }+ \text { trace } \\
\text { nutrients }\end{array}$ & 34,6 & 25,6 & 34,0 & 25,1 \\
\hline $\begin{array}{l}\text { Rhizohumin* }+ \\
\text { growth regulator }\end{array}$ & 34,9 & 25,1 & 33,5 & 24,7 \\
\hline $\begin{array}{l}\text { Rhizohumin } *+\text { trace } \\
\text { nutrients }+ \text { growth regulator }\end{array}$ & 35,2 & 25,7 & 34,0 & 24,7 \\
\hline LSD05 & 3,06 & 3,04 & 1,95 & 1,52 \\
\hline
\end{tabular}

Note: ${ }^{* *}$ - protein content, $\%$; $* * *$ - fat content, $\%$. 
Thus, the preformed studies have showed the perspectives of using the microbial preparation Rhizohumin in terms of formation and functioning of nitrogen fixing symbiosis of soybean plants and Bradyrhizobium japonicum, crop productivity and grain quality growing soybean in black soil with low humus content in a northern steppes of Ukraine. Realization of soybean productivity potential can be implemented through the foliar spraying of trace nutrients and plant growth stimulator of bacterized plants. 